University of Wollongong

Research Online

Faculty of Law, Humanities and the Arts Papers (Archive)

Faculty of Arts, Social Sciences \& Humanities

$1-1-2018$

South China Sea Arbitration and its Application to Dokdo

Seokwoo Lee

Inha University

Leonardo Leonardo

University of Wollongong, Ib987@uowmail.edu.au

Follow this and additional works at: https://ro.uow.edu.au/lhapapers

Part of the Arts and Humanities Commons, and the Law Commons

Research Online is the open access institutional repository for the University of Wollongong. For further information contact the UOW Library: research-pubs@uow.edu.au 


\title{
South China Sea Arbitration and its Application to Dokdo
}

\author{
Abstract \\ On 12 July 2016, the Arbitral Tribunal formed under Annex VII of the 1982 United Nations Convention on \\ the Law of the Sea issued its decision on the proceeding brought by the Philippines against China relating \\ to certain activities in the South China Sea. The Tribunal's decision was hotly anticipated as it dealt with \\ various important issues relating to law of the sea and the interpretation of the Convention. It dealt with \\ issues including the jurisdiction of the Tribunal, the legal status of maritime features, historic rights, and \\ duty to preserve the marine environment. Although it remains to be seen whether states will follow the \\ Tribunal's precedent, questions arose on whether such precedent can be applied to other unresolved \\ issues in other parts of the world. This paper looks at the application of the precedent established by the \\ South China Sea arbitration to the situation involving Dokdo between Korea and Japan.

\section{Disciplines} \\ Arts and Humanities | Law \\ Publication Details \\ S. Lee \& L. Bernard, 'South China Sea Arbitration and its Application to Dokdo' (2018) 8 (1) Asian Journal \\ of International Law 24-35.
}




\title{
South China Sea Arbitration and its Application to Dokdo
}

\author{
Seokwoo LEE* \\ University Law School, Republic of Korea \\ [leeseokwoo@inha.ac.kr] \\ Leonardo BERNARD ${ }^{* *}$ \\ University of Wollongong, Australia \\ [lb987@uowmail.edu.au]
}

\begin{abstract}
On 12 July 2016, the Arbitral Tribunal formed under Annex VII of the 1982 United Nations Convention on the Law of the Sea issued its decision on the proceeding brought by the Philippines against China relating to certain activities in the South China Sea. The Tribunal's decision was hotly anticipated as it deals with various important issues relating to law of the sea and the interpretation of the Convention. It dealt with issues including the jurisdiction of the Tribunal, legal status of maritime features, historic rights and duty to preserve the marine environment. Although it remains to be seen whether States will follow the Tribunal's precedent, questions arose on whether such precedent can be applied to other unresolved issues in other parts of the world. This article looks at the application of the precedent established by the South China Sea arbitration to the situation involving Dokdo between Korea and Japan.
\end{abstract}

On 12 July 2016, the Arbitral Tribunal formed under Annex VII of the 1982 United Nations Convention on the Law of the Sea (UNCLOS) ${ }^{1}$ issued its decision on the proceeding brought by the Philippines against China relating to certain activities in the South China Sea. ${ }^{2}$ The award deals with various important issues relating to law of the sea and the interpretation of UNCLOS, such as the jurisdiction of the Tribunal, legal status of maritime features, historic rights, and duty to preserve the marine environment. The impact of the award is felt worldwide, as it would undoubtedly influence other unresolved issues in other parts of the world involving islands and maritime features. This is the case particularly in East Asia, where the Republic of Korea's (Korea) occupation of Dokdo is challenged by Japan.

Like China and the Philippines, both Korea and Japan are parties to UNCLOS. ${ }^{3}$ Like China, South Korea on 18 April 2006 also made a declaration under paragraph 1 of Article 298 to exclude the issue of maritime boundary delimitation and military activities in the exclusive economic zone (EEZ) from the compulsory dispute settlement mechanism under

\footnotetext{
* Professor, Inha University Law School, Republic of Korea.

** PhD Candidate, Australian National Centre for Ocean Resources \& Security (ANCORS), University of Wollongong, Australia.

${ }^{1}$ United Nations Convention on the Law of the Sea, 10 December 1982, 1833 U.N.T.S. 3 (entered into force 16 November 1994) [UNCLOS].

${ }^{2}$ The Republic of the Philippines v. The People's Republic of China, Award on the Merits [2016] Permanent Court of Arbitration Case No. 2013-19, 12 July 2016.

${ }^{3}$ Korea ratified UNCLOS on 29 January 1996, while Japan ratified on 20 June 1996. See UN Division for Ocean Affairs and the Law of the Sea, "Chronological Lists of Ratifications of Accessions and Successions to the Convention and the Related Agreements", online: UN

<http://www.un.org/depts/los/reference_files/chronological_lists_of_ratifications.htm>.
} 
section 2 of Part XV of UNCLOS. ${ }^{4}$ Despite of the fact that UNCLOS does not deal with any dispute regarding territorial sovereignty, and despite of China's declaration to exclude maritime delimitation from the compulsory dispute settlement mechanism of UNCLOS, the Philippines managed to bring China in front of an arbitral tribunal and successfully obtained a ruling that some of China's occupation and activities in the South China Sea are unlawful. Thus, can one party unilaterally bring a case under Part XV of UNCLOS on the issue of occupation and activities in Dokdo? This article will discuss the relevance of the award on the arbitration case between the Philippines and China, and its relevance to the issue between Japan and Korea regarding Dokdo.

\section{THE ARBITRATION CASE BETWEEN THE PHILIPPINES AND CHINA}

The arbitration case against the People's Republic of China (hereinafter China) was brought by the Government of the Philippines on 22 January 2013, challenging China's maritime claims in the South China Sea. ${ }^{5}$ The case was brought under the compulsory dispute settlement mechanism under UNCLOS, to which both the Philippines and China are parties. ${ }^{6}$ In addition to challenging the legality of China's maritime claims, the Philippines questions whether some features in the South China Sea are entitled to generate an EEZ even though they are so small that it is almost impossible for these features to be inhabited. ${ }^{7}$

Both China and the Philippines claim sovereignty over most of the Spratly Islands in the South China Sea. UNCLOS, however, does not prescribe any procedure for the determination of sovereignty and instead only sets out what maritime zones may be claimed from land territory (including islands), as well as the rights and jurisdiction of States in such maritime zones. ${ }^{8}$ In its Statement of Claim, the Philippines astutely avoids the question of sovereignty and argues that no matter who has sovereignty over the features in the South China Sea, there are still legal questions on whether some of those features are entitled to generate an EEZ and continental shelf. ${ }^{9}$

When the arbitration case was initiated, China asserted that the tribunal was formed without any legitimacy and thus did not join the proceeding to formally challenge the Tribunal's jurisdiction over the case. ${ }^{10}$ China has staunchly snubbed the proceeding and has

\footnotetext{
${ }^{4}$ Republic of Korea, "Declaration Made after Ratification" UN (18 April 2006), online: UN

$<$ http://www.un.org/depts/los/convention_agreements/convention_declarations.htm\#RepKorea\%20after\%20rati fication>.

${ }^{5}$ Republic of the Philippines Department of Foreign Affairs Manila, "Notification and Statement of Claims, No 13-0211” Philippine Embassy (22 January 2013), online: Philippine Embassy <http://www.philippineembassyusa.org/uploads/pdfs/embassy/2013/2013-0122-

Notification\%20and\%20Statement\%20of\%20Claim\%20on\%20West\%20Philippine\%20Sea.pdf $\geq$.

${ }^{6}$ The Philippines ratified UNCLOS on 8 May 1984, while China ratified on 7 June 1996. See UN Division for Ocean Affairs and the Law of the Sea, "Chronological Lists of Ratifications of Accessions and Successions to the Convention and the Related Agreements", online: UN

<http://www.un.org/depts/los/reference_files/chronological_lists_of_ratifications.htm>.

${ }^{7}$ Notification and Statement of Claim of the Philippines, supra note $\overline{5}$, at para. 31.

${ }^{8}$ UNCLOS sets out a legal order for the seas and oceans to facilitate international communication and promote peaceful uses of the seas and oceans, equitable and efficient utilization of their resources, conservation of their living resources and study, protection and preservation of the marine environment; see the Preamble of UNCLOS.

${ }^{9}$ Notification and Statement of Claim of the Philippines, supra note 5, at para. 31.

${ }^{10}$ PCA Press Release, “Arbitration between the Republic of the Philippines and the People's Republic of China: Arbitral Tribunal Establishes Rules of Procedure and Initial Timetable” (27 August 2013), online: PCA <https://pcacases.com/web/sendAttach/227>.
} 
refused to participate in any stage of the arbitral process. China's non-participation, however, does not prevent the arbitral proceedings from going ahead and the Tribunal from making an award. ${ }^{11}$ As the 16 December 2014 deadline set by the Tribunal for China to respond to the Philippines' written submission got closer, China seemed to have changed its mind and decided that it was necessary to make its position known to the Tribunal, in one way or another. On 7 December 2014, exactly ten days before the deadline, China published a Position Paper detailing why they believe the Tribunal lacks jurisdiction to consider the case. $^{12}$

\section{A. The Positions of the Philippines and China on the Arbitration Case}

Most of the features that can be considered as "islands" in the Spratly Islands are small, remote and not capable of sustaining human habitation or economic life of their own. ${ }^{13}$ Thus, they are likely to be classified as "rocks", and would only be entitled to a 12 nautical mile (M) territorial sea. ${ }^{14}$ This seems to be the position taken by the Philippines in this case, which prevents whoever owns the islands from claiming resources beyond $12 \mathrm{M}$ of each "rock". 15 Since most of these "rocks" are located within the $200 \mathrm{M}$ limit of the Philippines' EEZ entitlement generated from its main islands, the Philippines argues that the only disputed waters are the territorial seas surrounding each rock, ${ }^{16}$ thus leaving a large part of the waters and the seabed under the exclusive jurisdiction of the Philippines. The Philippines does not recognize the legitimacy of China's historic claim to the resources in and under the waters inside the nine-dash line, which is the main basis of China's maritime claim. ${ }^{17}$ The Philippines also claimed that China has violated its rights under Articles 56 and 77 of UNCLOS and that there is a dispute between the parties on the interpretation of Article 121 of UNCLOS and on the legality of China's claim to rights and jurisdiction inside the ninedash line. ${ }^{18}$

In the Position Paper, China argues that the case involves sovereignty disputes over land territories, which is not covered by UNCLOS. Even if the Tribunal decided to distinguish the sovereignty dispute from the maritime dispute, China argues that the maritime dispute is so intertwined with the issue of maritime delimitation that it is impossible to settle one without affecting the other. ${ }^{19}$ Since China has made a declaration to exclude any disputes concerning maritime delimitation from the jurisdiction of the UNCLOS dispute settlement

\footnotetext{
${ }^{11}$ See generally UNCLOS, Annex VII, at Art. 9.

${ }^{12}$ Ministry of Foreign Affairs of the People's Republic of China, "Position Paper of the Government of the People's Republic of China on the Matter of Jurisdiction in the South China Sea Arbitration Initiated by the Republic of the Philippines", Position Paper, 7 December 2014 (hereinafter the "Position Paper").

${ }^{13}$ For further details on the geographical description of the features in the Spratly Islands, see David HANCOX and Victor PRESCOTT, "A Geographical Description of the Spratly Islands and an Account of Hydrographic Surveys Amongst those Islands" (1995) 6 IBRU Maritime Briefings 1.

${ }^{14}$ UNCLOS, supra note 1, at Art. 121(3).

${ }^{15}$ The Philippines challenges the maritime claims that can be made from the disputed "rocks" currently occupied by China (the Scarborough Shoal, Johnson Reef, Cuarteron Reef, and Fiery Cross Reef). The Philippines also argues that the geographic features in the Spratly Islands that are currently occupied by China (Mischief Reef, McKennan Reef, Gaven Reef, and Subi Reef) do not meet the definition of an island as set out in Article 121(1) of UNCLOS. See Notification and Statement of Claim of the Philippines, supra note 5.

${ }^{16}$ Ibid.

${ }^{17}$ Ibid, at para. 11-2.

${ }^{18}$ See Arbitration between the Republic of the Philippines and the People's Republic of China, Award on Jurisdiction and Admissibility [2015] Permanent Court of Arbitration Case No. 2013-19, 29 October 2015, at para. 169.

${ }^{19}$ Position Paper, supra note 12, at para. 14.
} 
regime ${ }^{20}$ China asserted that the tribunal was formed without any legitimacy and thus has refused to participate in any stage of the arbitral process. ${ }^{21}$ The Philippines argued that such disputes are not excluded by China's declaration because they would not require the tribunal to delimit the maritime boundary in the area or determine which State has sovereignty over the islands and other geographic features in the area. ${ }^{22}$

Although China has made it clear that the Position Paper should not be regarded as "China's acceptance of or its participation in the arbitration", ${ }^{23}$ it remains the only official statement of China's position regarding its objection to the jurisdiction of the Tribunal. The Tribunal, having had no response or argument whatsoever to consider from China, seized upon the Position Paper and decided to treat it as "constituting a plea concerning the Tribunal's jurisdiction". ${ }^{24}$

\section{B. The Decisions of the Arbitral Tribunal}

Since the Tribunal has had formal arguments from both sides - at least on the issue of jurisdiction - it has decided to conduct a hearing to address the objections to jurisdiction as set out in China's Position Paper. ${ }^{25}$ On 16 March 2015, the Philippines submitted a Supplemental Submission to The Hague-based Tribunal. ${ }^{26}$ The Supplemental Submission was in response to the request by the Tribunal for additional argument and information regarding both the tribunal's jurisdiction and the merits of the Philippines' claims challenging the lawfulness of China's claims. The Tribunal gave China until 16 June 2015 to comment on the Philippines' Supplemental Submission, ${ }^{27}$ but the deadline came and went without any response from China. ${ }^{28}$

On 29 October 2015, the Tribunal issued its Award on Jurisdiction and Admissibility, in which the Tribunal decided that it has jurisdiction to hear the dispute regarding the interpretation of Article 121 of UNCLOS in relation to the status of Scarborough Shoal, Johnson Reef, Cuarteron Reef and Fiery Cross Reef as "islands" or "rocks", as well as the status of Mischief Reef, Second Thomas Shoal, Subi Reef, Gaven Reef, and McKennan Reef as low tide elevations. ${ }^{29}$ The Tribunal also found that it has jurisdiction to consider the disputes concerning China's alleged interference with the traditional fishing activities of the Philippine nationals within the territorial sea of Scarborough Shoal, the protection and

\footnotetext{
${ }^{20}$ China has made a formal declaration excluding maritime boundary delimitation claims from the Convention's compulsory binding dispute settlement mechanism and this is one of the main reasons why China refuses to accept the jurisdiction of the ad hoc arbitration tribunal formed under UNCLOS. See UN Division for Ocean Affairs and the Law of the Sea, "Declaration Under Article 298 by the Government of the People's Republic of China" (25 August 2006), online: UN

$<$ http://www.un.org/depts/los/convention_agreements/convention_declarations.htm\#China Upon ratification>.

${ }^{21}$ China's "Note Verbale" to the Permanent Court of Arbitration, supra note 10.

${ }^{22}$ Notification and Statement of Claim of the Philippines, supra note 5, at para. 40.

${ }^{23}$ Position Paper, supra note 12.

${ }^{24}$ Permanent Court of Arbitration, "The Arbitral Tribunal Sets Dates for Hearing on Jurisdiction and Admissibility”, Fourth Press Release, 22 April 2015, online: PCA

<https://pcacases.com/web/sendAttach/1298>.

${ }^{25}$ Award on Jurisdiction and Admissibility, supra note 18.

${ }^{26}$ Department of Foreign Affairs, Republic of the Philippines, "Statement on the Philippines' Supplemental Submission to the Arbitral Tribunal", 16 March 2015, online: PCA <https://files.pcacpa.org/pcadocs/Supplemental\%20Written\%20Submission\%20Volume\%20I.pdf >.

${ }^{27}$ See the Press Release of the Permanent Court of Arbitration, supra note 24.

${ }^{28}$ Award on Jurisdiction and Admissibility, supra note 18, at para. 75.

${ }^{29}$ See ibid., at para. 407.
} 
preservation of the marine environment at Scarborough Shoal and Second Thomas Shoal, as well as China's law enforcement activities in the vicinity of Scarborough Shoal. ${ }^{30}$ The Tribunal, however, decided to reserve the decision on its jurisdiction with respect of the rest of the Philippines' submissions, including the issue of maritime entitlement in the South China Sea, to be considered with the merits of the case. ${ }^{31}$

The Tribunal issued its decision on the merits of the case on 12 July 2016. The decision gave an almost sweeping victory to the Philippines, where the Tribunal declared that China cannot use its nine-dash $\operatorname{line}^{32}$ to claim any rights over maritime resources or any entitlement to maritime zones. ${ }^{33}$ The Tribunal also declares that none of the maritime features in the Spratly Islands are capable in generating EEZ or continental shelf, effectively categorizing all maritime features there as a "rock" under Article 121(3) of UNCLOS. ${ }^{34}$ Based on these findings, the Tribunal then concluded that China's activities on and around certain features in the Spratly Islands were in detriment of Philippines' rights and not consistent with UNCLOS. ${ }^{35}$ These activities will be discussed in more details below.

\section{RELEVANCE OF THE SOUTH CHINA SEA DECISION TO THE DOKDO SITUATION}

Dokdo (Takeshima) is an island consisting of two islets, Dongdo and Seodo, located almost halfway between Korea and Japan in the East Sea (Sea of Japan). ${ }^{36}$ It has a total area of 56 acres and is about 100-174 metres high. ${ }^{37}$ The island has been under continuous Korea's administration since 1952, ${ }^{38}$ but this is challenged by Japan. ${ }^{39}$ The issue of Dokdo continues to be a source of tension and a thorn on the bilateral relationship between Korea and Japan. At one point in 1954, Japan even asked Korea to refer the dispute to the International Court of Justice (ICJ), which was rejected by Korea. ${ }^{40}$ Korea does not see any reason why it should bring a matter concerning a territory that it exerts effective control over and that it consider to legally belonging to it to the ICJ. ${ }^{41}$ Without Korea's consent, there is no chance that Japan could challenge Korea's sovereignty over Dokdo at the ICJ or other international tribunal. However, the award of the arbitral tribunal in the South China Sea dispute created a precedent on how a State can unilaterally bring another State to a third party adjudication.

\section{A. Sovereignty Issue}

\footnotetext{
${ }^{30}$ Ibid., at para. 408 and 410.

${ }^{31}$ Ibid., at para. 398-412.

32 The nine-dash line was drawn in 1947 by the then Chinese Nationalist Government and was first published in February 1948. Originally, the map showed the Pratas Islands, the Paracel Islands, the Macclesfield Bank, and the Spratly Islands as being "part" of China with the use of an eleven-dashed line. The two-dashed line in the Gulf of Tonkin was deleted in 1953 with the approval of the then Premier Zhou Enlai. See LI Jinming and LI Dexia, "The Dotted Line on the Chinese Map of the South China Sea: A Note" (2003) 34 Ocean Development \& International Law 287 at 290.

${ }^{33}$ Award on the Merits, supra note 2, at 473.

${ }^{34}$ Ibid., at 474.

${ }^{35}$ Ibid., at 475.

${ }^{36}$ HYUN Dae-song, "The Dokdo-Takeshima Issue: Its Origins and the Current Situation", in HYUN Dae-song, ed., The Historical Perceptions of Korea and Japan (South Korea: NANAM Publishing House, 2008) 37 , at 37. ${ }^{37}$ Ibid.

${ }^{38}$ LI Jin-mieung, Dokdo: A Korean Island Rediscovered (South Korea: Northeast Asian History Foundation, 2010), at 9. See also ibid., at 38.

${ }^{39}$ Hyun, supra note 36 , at $38-9$.

${ }^{40}$ Ibid., at 77.

${ }^{41} \mathrm{Li}$, supra note 38 , at 11 .
} 
On the South China Sea dispute, UNCLOS is clear that it does not deal with any dispute regarding territorial sovereignty. Despite of this, the Philippines managed to successfully obtain a ruling that China's occupation of Mischief Reef are unlawful. ${ }^{42}$ Since the Tribunal accepted that it has jurisdiction to hear the issue regarding China's occupation of Mischief Reef, questions have been raised on whether such strategy can be deployed to other unresolved issues in other parts of the world involving islands and maritime features, especially Dokdo.

As was the case with the South China Sea arbitration, any challenges to the sovereignty over Dokdo cannot be resolved by UNCLOS. So can similar strategy used in the South China Sea dispute be used in Dokdo situation? For example, can Japan unilaterally bring South Korea to arbitration to challenge the latter's occupation of Dokdo? The short answer is no. The issue regarding "occupation" relates to sovereignty, which as mentioned above is not under the purview of UNCLOS.

So how could the Arbitral Tribunal that was formed under UNCLOS in the South China Sea case ruled on the occupation of Mischief Reef? This relates to another claim brought by the Philippines in the case, which argued that Mischief Reef is not an island or rock, but a low tide elevation. The status of Mischief Reef is important in determining whether the Tribunal has jurisdiction to hear the occupation challenge. If Mischief Reef is deemed as an island - or even a rock for that matter - it is subject to sovereignty claim, and thus the Tribunal would not have jurisdiction to hear any challenges on its occupation. ${ }^{43}$ However, in its decision the Tribunal found that Mischief Reef is a low-tide elevation and not a rock or island entitled to any maritime zones. ${ }^{44}$ The consequence of this finding is that Mischief Reef is incapable of appropriation, by occupation or otherwise. Instead, jurisdiction over Mischief Reef lies on the coastal State in whose EEZ or continental shelf those features are located. In this case, the Tribunal ruled that Mischief Reef is located within Philippines' EEZ, and thus it is under the jurisdiction of the Philippines. ${ }^{45}$

The situation regarding Dokdo Island is different from Mischief Reef. Dokdo is a naturally formed land that is above water at high tide, which qualifies it as an island or at least a rock under Article 121 of UNCLOS. Neither Japan nor Korea ever challenged the status of Dokdo as a high tide feature that can be claimed under international law. Since Dokdo is subject to sovereignty claim, the sovereignty of Dokdo is not an issue under the purview of UNCLOS. Thus, Korea cannot be forced to go to the ICJ or other international tribunal to justify the legality of its occupation of Dokdo.

\section{B. Status of Dokdo as a Rock or an Island}

The Arbitral Tribunal's determination in the South China Sea dispute between the Philippines and China included a long-awaited articulation of the distinction between "islands" capable of generating extended maritime claims (that is, EEZ and continental shelf entitlements) and "rocks" which can only generate a $12 \mathrm{M}$ territorial sea. The decision set a high bar for a feature to constitute a "fully-fledged" island capable of generating the full suite of maritime

\footnotetext{
${ }^{42}$ Award on the Merits, supra note 2, at 476.

${ }^{43}$ Ibid., at para. 1024.

${ }^{44}$ Ibid., at para. $374-8$.

${ }^{45}$ Ibid., at para. 1025.
} 
zones. ${ }^{46}$ In particular, the Tribunal determined that there are no islands in the Spratly group in the South China Sea capable of generating EEZ and continental shelf. ${ }^{47}$ Extension of this logic to Dokdo would likely lead to a conclusion that Dokdo is a rock, which only entitled to a $12 \mathrm{M}$ territorial sea.

The question is whether the Award in the South China Sea dispute will endure and be influential in future judicial determinations or whether State practice will evolve in a way that is inconsistent with the decision. The decision may either have diminishing influence on future cases as time goes on, or it might be treated as an authoritative ruling that will have enduring effect. If State practice supports the decision then the better legal view is that Dokdo would be treated as a rock. Yet will a future court take a broader view of "rock" for features which are close to the mainland? Coastal States typically favor maximizing their maritime jurisdiction by claiming full entitlement for even extremely small, remote, and unpopulated islands. This raised the prospect of State practice being unaffected by the Award.

Whether State practice would follow the jurisprudence of the Award, the South China Sea Arbitration is now the starting point of discussion regarding whether a feature is a rock or island. The legal status of Dokdo may or may not be a dispute between Korea and Japan. Nevertheless, the approach in the Award, when applied, would seem to lead to a conclusion that Dokdo is a rock.

\section{The Delimitation Issue}

In the South China Sea arbitration, China argued that the Tribunal lacks jurisdiction because the disputes submitted by the Philippines "would constitute an integral part of maritime delimitation between the two countries". ${ }^{48}$ Although UNCLOS does contain provisions concerning the delimitation of maritime boundaries, China's declaration under Article 298 excluded the issue of maritime boundary delimitation from the Tribunal's jurisdiction. ${ }^{49}$ This is a point that the Philippines were aware of, which was why it did not asked the Tribunal to delimit any maritime boundary between the Parties. ${ }^{50}$ In its decision, the Tribunal made it clear that it will only address the Philippines' claims "only insofar as the two Parties' respective rights and obligations are not dependent on any maritime boundary or where no delimitation of a boundary would be necessary because the application of the Convention would not lead to any overlap of the two Parties' respective entitlements". 51

Similarly, South Korea made a declaration under Article 298 to exclude any disputes relating to maritime delimitation and military activities in the EEZ from the compulsory

\footnotetext{
46 The Tribunal found that " $\mathrm{t}] \mathrm{h}$ he term 'human habitation' should be understood to involve the inhabitation of the feature by a stable community of people for whom the feature constitutes a home and on which they can remain". The Tribunal continues by stating that "the term 'economic life of their own' is linked to the requirement of human habitation, and the two will in most instances go hand in hand". See Award on the Merits, supra note 2, at para. 542-3.

${ }^{47}$ Ibid., at para. 626.

${ }^{48}$ Position Paper, supra note 12.

${ }^{49}$ For the up-to date official texts of declarations and statements that contain optional exceptions to the applicability of Part XV, Section 2, under Article 298 of UNCLOS, see UN, "Settlement of Disputes Mechanism" UN (20 June 2017), online: UN

<www.un.org/Depts/los/settlement_of_disputes/choice_procedure.htm>.

${ }^{50}$ Notification and Statement of Claim of the Philippines, supra note 5, at para. 40.

${ }^{51}$ Award on the Merits, supra note 2, at para. 6.
} 
dispute settlement mechanism under UNCLOS. Hence, any issue regarding maritime delimitation around Dokdo between the two countries cannot be brought under the compulsory dispute settlement mechanism under UNCLOS. However, it is important to note that the characterization of Dokdo as a rock or island will have consequences for Korea's claim of maritime jurisdiction around Dokdo, and the effect of Dokdo in any maritime delimitation with Japan. Given Dokdo's location in the central part of the East Sea (Sea of Japan), its influence in determining the EEZ/continental shelf boundary delimitation between Korea and Japan is significant. Past jurisprudence on maritime delimitation cases and state practice suggest that a modified equidistance line, potentially including an enclaving or semienclaving treatment of Dokdo, is a plausible final outcome.

\section{Fishing Activities Around Dokdo}

One of the claims brought by the Philippines was that China has interfered with the Philippines' sovereign rights and jurisdiction to exploit the fisheries resources in its EEZ by enacting and enforcing "laws and regulations that purport to extend China's law enforcement jurisdiction, including over fishing resources, throughout the entire area encompassed by the nine-dash line". ${ }^{52}$ As part of its Article 298 Declaration, China has excluded any law enforcement activities relating to fisheries in its EEZ from the compulsory dispute settlement mechanism. However, the Tribunal found that China has no EEZ entitlement around the Spratly Islands, leaving no overlap with the Philippines' EEZ. Hence, China's law enforcement activities within the Philippines' EEZ are not excluded from the jurisdiction of the Tribunal.

The situation with Dokdo is slightly different from the South China Sea. Korea never claims EEZ generated from Dokdo. Despite of this, there is an overlap of entitlement between EEZ generated from Korean Peninsula and the EEZ generated from Japan's archipelago. Although no EEZ boundaries have been agreed on the area, both countries have reached an agreement on fisheries that theoretically gives both parties equal fishing rights in the area, except within $12 \mathrm{M}$ of Dokdo. ${ }^{53}$ Thus, unless Korea is enforcing its laws in the area designated to Japan based on the agreement, there is no way to challenge Korea's law enforcement activities in its own EEZ as this has been excluded by Korea's Article 298 Declaration.

The problem however, is less about fishing enforcement in the EEZ of Korea, and more about the possibility of Japanese fishermen fishing in the sea within $12 \mathrm{M}$ of Dokdo which had happened in the past. ${ }^{54}$ Article 298 excludes law enforcement activities regarding fisheries in the EEZ, but not in the territorial sea. In theory, any law enforcement issues within the $12 \mathrm{M}$ territorial sea is subject to the compulsory dispute settlement mechanism of UNCLOS. However, in the Dokdo situation, any issue relating to the territorial sea of Dokdo depends on the sovereignty issue over the island, which is not under the purview of UNCLOS. Hence, any court or tribunals formed under UNCLOS would not have jurisdiction to decide on the matter.

\section{E. Preservation of the Marine Environment}

\footnotetext{
${ }^{52}$ Ibid., at para. 686.

${ }^{53} \mathrm{Li}$, supra note 38 , at 9.

${ }^{54}$ Ibid.
} 
Even if Japan cannot challenge the occupation of Dokdo to the dispute settlement mechanism under UNCLOS, can Japan challenge South Korean activities in the waters surrounding Dokdo? The short answer is yes. However, further examination of the kind of activities that can be challenged is needed. China - as well as South Korea - has made a declaration excluding any issue regarding military activities from the compulsory jurisdiction of UNCLOS. In the Mischief Reef situation, however, China has repeatedly stated that the construction is not military in nature. Thus, such construction activities are not excluded from the jurisdiction of the Tribunal.

China's massive construction projects raise serious concerns about their effects on the marine environment. China claims that the ecological environment of the South China Sea has not been damaged, and that the construction projects on the islands and reefs followed a high standard of environmental protection, taking into full consideration the protection of ecological environment and fishing resources. ${ }^{55}$ The Philippines slammed this assertion, stating that China's ongoing reclamation activities "are causing irreversible and widespread damage to the biodiversity and ecological balance to waters". 56

This seems to be a valid argument raised by the Philippines. Since three of the features on which China is undertaking reclamation works in the South China Sea are either just inside or just outside the limit of the EEZ claimed by the Philippines, it is reasonable for the Philippines to argue that China has the obligation to notify the Philippines about its reclamation plans, to assess the environmental impact of the reclamation projects and to share the result of such assessment with the Philippines. ${ }^{57}$ Moreover, since the reefs being reclaimed by China are either being disputed or located in the middle of an area that is being disputed, China cannot take unilateral action that would permanently change the status quo of these reefs. ${ }^{58}$

Having established jurisdiction, the Tribunal considered the effect on the marine environment of China's large-scale land reclamation and construction of artificial islands in the Spratly Islands and found that China has breached its obligation under Article 192 of UNLCOS to protect and preserve the marine environment. ${ }^{59}$ The Tribunal considers that given the scale and impact of the island-building activities, China was required to prepare an environmental impact assessment (EIA) and to communicate the results of the assessment. ${ }^{60}$ The Tribunal found that China's failure to communicate the results of the EIAs that it had allegedly conducted with the Tribunal, Meeting of States Parties to the UNCLOS, or any other international organization, as breach of the obligation of co-operation enshrined under Article 206 of UNCLOS. ${ }^{61}$

\footnotetext{
${ }^{55}$ Ministry of Foreign Affairs of the People's Republic of China, "Foreign Ministry Spokesperson Hua Chunying's Regular Press Conference on April 9, 2015”, online: Ministry of Foreign Affairs of the People's Republic of China <http://www.fmprc.gov.cn/mfa_eng/xwfw_665399/s2510_665401/t1253488.shtml>.

${ }^{56}$ Michaela DEL CALLAR, "Chinese claim of South China Sea reclamation not causing damage unacceptable -DFA", 13 April 2015, online: GMA News Online

<http://www.gmanetwork.com/news/news/nation/468746/chinese-claim-of-south-china-sea-reclamation-notcausing-damage-unacceptable-dfa/story/>.

${ }^{57}$ See Case Concerning Land Reclamation by Singapore in and around the Straits of Johor (Malaysia $v$. Singapore), Provisional Measures [2003] ITLOS, Order of 8 October 2003.

${ }^{58}$ Guyana v. Suriname, Award [2007] Permanent Court of Arbitration Case No. 2004-04, 17 September 2007, at para. 407.

${ }_{59}$ Award on the Merits, supra note 2, at para. 983.

${ }^{60}$ Ibid., at para. 988 .

${ }^{61}$ Ibid., at para. 991.
} 
The duty to protect and preserve the marine environment is contained in Part XII of UNCLOS, which is applicable to all States with respect to the marine environment in all maritime areas, both inside the national jurisdiction of States and beyond it. In the East Sea (Sea of Japan) context, as a State party of UNCLOS, Korea is bound by the provisions of Part XII, and has a duty to protect and preserve the marine environment, not only in the waters surrounding Dokdo, but in all maritime areas. In conducting activities in the waters around Dokdo, Korea must ensure that such activities would not harm the marine environment. Following the Award, Korea should also aware that before conducting any activities around Dokdo that may affect the marine environment, Korea not only has to conduct an EIA, but also required to share the result of such assessment, including to Japan. If Korea fails to observe such obligation, it would be in violation of UNCLOS, and other State parties of UNCLOS - including Japan - could bring a claim against Korea regarding such violation. However, if such activities are military in nature, due to Korea's declaration, they would be excluded from the jurisdiction of the compulsory dispute settlement mechanism under UNCLOS.

\section{CONCLUSION}

The issues regarding Dokdo between Korea and Japan are mainly related to Korea's sovereignty over Dokdo which is challenged by Japan, as well as the effect Dokdo on maritime delimitation between the two countries. If international judicial dispute settlement is sought on both issues at the same time, the case could take a long time to be completed. Nevertheless, the determination of sovereignty over Dokdo without the logical second phase of delimitation of maritime boundary is unlikely to resolve the issue between Korea and Japan. It is unlikely, however, that the issues of sovereignty over Dokdo and maritime delimitation between Korea and Japan will be brought in front of an international judicial dispute settlement body without the consent of both parties. Dispute settlement mechanism under UNCLOS also would not be able to hear the disputes, not only because the issue sovereignty is outside of the scope of the Convention, but also because Korea and Japan have both expressly excluded maritime delimitation from the application of the dispute settlement mechanism under UNCLOS. Following this, since no international court or tribunal could resolve the sovereignty issue of Dokdo, any issue regarding fishing activities within $12 \mathrm{M}$ of Dokdo also would not be able to be resolved, as this would depend on the determination of which country has sovereignty over Dokdo.

However, the Arbitral Award in the case between the Philippines and China raises concern about the broad jurisdiction being assumed by arbitral tribunals - as well as by the International Tribunal for the Law of the Sea (ITLOS) - something that might lead Korea to engagement in a judicial case "by accident". For example, action on the part of the Korea in the waters around Dokdo, for instance the construction of an ocean research station proximate to Dokdo as has been contemplated in recent years, could conceivably leave Korea open to involvement in a case brought by Japan under the dispute resolution mechanisms provided for under UNCLOS. This is because such activities on the part of Korea could be construed as matters directly related to the interpretation of aspects of UNCLOS, especially the obligation to protect and preserve the marine environment under Article 192 and the duty to cooperate under Article 206. These questions would therefore not be covered by the exclusions set out in Article 298 of UNLCOS which Korea invoked in its Declaration of 18 April 2006. While any such challenge could not address the question of sovereignty over Dokdo, such a development may be unwelcome from a Korean perspective, for instance 
potentially leading to a judicial pronouncement not only concerning the lawfulness of activities undertaken by Korea and whether such actions constitute an aggravation of the dispute, but also concerning the status of Dokdo as an island or rock. 